\title{
The Distributional Impact of Year 2000 Tax Reforms in Australia
}

\author{
Ann Harding, Neil Warren, Martin Robinson \\ and Simon Lambert
}

$\mathrm{W}$ henever major tax reform packages are proposed, one of the areas of fiercest debate is always about the distributional impact of the reforms - who wins, who loses, and by how much. When major shifts in the tax mix are suggested - away from income tax and towards consumption taxes - the distributional issues always assume particular prominence because of concern about the impact of such changes on the most vulnerable groups in the community. It is arguable that the previous two attempts at tax mix shifts in the mid 1980s and early 1990s failed in large part because of concerns about their distributional impact (Treasury, 1985; Liberal and National Parties, 1991). So when the Howard Government laid out a comprehensive 200 page tax reform plan in August 1998 and then held an election on this issue, there was intense public interest in whether or not the new tax system would be fairer (Treasurer, 1998).

Estimates of the distributional impact of the package were prepared by the Treasury and included in the document released by the Treasurer. But aspects of the methodology underlying these estimates differed from that used in previous attempts in this area. Ultimately, the Australian Senate set up the Committee on a New Tax System to evaluate the Government's tax reform package. That Committee asked us to examine the distributional impact of the reforms, in some cases using assumptions that were different from those made by the Treasury (Warren et al, 1999a).

Subsequently, in May 1999, the Commonwealth Government negotiated a compromise agreement with the Australian Democrats and the new tax package is now being introduced on 1 July 2000 . This compromise resulted in food being removed from the GST base, compensation to pensioners being increased and better protected, changes to the taxation of petroleum products, reductions in tax cuts for high income individuals, and the deferred abolition of a number of State taxes.

\footnotetext{
Ann Harding is Professor of Applied Economics and Social Policy and Director of the National Centre for Social and Economic Modelling (NATSEM) at The University of Canberra; Neil Warren is Associate Professor of Economics at the Australian Taxation Studies Program (ATAX) at The University of New South Wales; Martin Robinson is a Research Fellow and Simon Lambert a Senior Research Fellow at NATSEM.
} 


\section{The Tax Reform Package}

The package originally proposed by the Government was complex, involving sweeping changes to indirect taxes, large cuts in income tax, and substantial reforms to social security and family assistance programs.

\section{Indirect tax reforms}

The original package proposed the following indirect tax reforms:

- A 10 per cent Goods and Services Tax (GST) on a broad base with health and medical care, education, childcare, charitable activities and religious services GST-free and residential rents and financial services input taxed.

- Abolition of the current wholesale sales tax.

- Abolition of a range of State taxes including Financial Institutions Duty; debits tax; stamp duty on marketable securities; conveyancing duties on business property; stamp duties on credit arrangements, instalment purchase arrangements and rental (hiring) agreements; stamp duties on leases; stamp duties on mortgages, bonds, debentures and other loan securities; stamp duties on cheques, bills of exchange and promissory notes; and 'bed taxes'.

- Introduction of taxes on wine and luxury cars to maintain the current effective consumption tax rates.

- Adjustments to excise duties following the imposition of a GST (but with a significant increase in the price of tobacco following the introduction of a per-stick system of excise duties on tobacco).

In the revised package, a number of major changes were made to the proposed indirect tax reforms. First, basic foods were removed from the base of the GST. Second, the removal of those State taxes initially proposed for abolition was either deferred or abandoned. The other main area of change to the indirect taxes was to the proposed Diesel GST Credit. This scheme was restructured into a rebate and reduced as part of a compromise involving increased environmentrelated subsidies.

The removal of food from the base of the GST was at a cost to revenue of $\$ 3.6$ billion in 2001-02, of which $\$ 1.2$ billion was funded via reductions in the top personal income tax marginal rates, and the remainder through changes to indirect taxes and subsidies (Warren et al, 1999b). In effect, two-thirds of the cost of removing food from the GST base was funded from increases in other indirect taxes (compared with the situation in the original package). Thus, somewhat paradoxically, the removal of food from the GST base was largely paid for by the re-imposition of other indirect taxes, which themselves will flow-through to the price of food and other commodities consumed by households. Nonetheless, the changes resulted in a 0.5 percentage point reduction in the likely impact of the package on the Consumer Price Index, from 3.2 per cent for the original package down to 2.7 per cent for the revised package (Warren et al, 1999b). 


\section{Income tax reforms}

The 1999-2000 personal income tax schedule is outlined in Table 1. This schedule has remained unchanged since 1 November 1993, so that wages growth has seen a growing proportion of the labour force pushed into the higher marginal tax brackets (Harding, 1998). Currently, the average full-time employee faces a marginal tax rate of 44.5 per cent (including the 1.5 per cent Medicare levy). This 'bracket creep' has been creating political problems for the government, as it is widely regarded as unfair that average families should be facing such high tax rates. This is one of the key reasons why the government originally proposed reducing the marginal tax rate for those with incomes between $\$ 38000$ and $\$ 50$ 000 a year from 43 to 30 per cent (Table 1).

However, the government's original package also proposed cutting the marginal tax rate for those earning from $\$ 50000$ to $\$ 75000$, from 47 to 40 per cent. Ultimately, the generosity of the tax cuts for such taxpayers was reduced in the final version of the package, amid concerns that high income earners were deriving excessive benefits from the package allied with the need to pay for the exclusion of food from the new GST base (Table 1)

Table 1: Current and Proposed Income Tax Scales

\begin{tabular}{lcccc}
\hline $\begin{array}{l}\text { Current 1999-2000 tax scales } \\
\begin{array}{l}\text { Taxable } \\
\text { income }\end{array}\end{array}$ & $\begin{array}{l}\text { Tax } \\
\text { rate }\end{array}$ & Taxable income & $\begin{array}{c}\text { 2000-2001 tax scales } \\
\text { Government's } \\
\text { original proposal }\end{array}$ & Final scales \\
\hline$\$ 0-\$ 5,400$ & 0 & $\$ 0-\$ 6,000$ & 0 & 0 \\
$\$ 5,401-\$ 20,700$ & $20 \%$ & $\$ 6,001-\$ 20,000$ & $17 \%$ & $17 \%$ \\
$\$ 20,701-\$ 38,000$ & $34 \%$ & $\$ 20,001-\$ 50,000$ & $30 \%$ & $30 \%$ \\
$\$ 38,001-\$ 50,000$ & $43 \%$ & & & $42 \%$ \\
$\$ 50,001+$ & $47 \%$ & $\$ 50,001-\$ 60,000$ & $40 \%$ & $47 \%$ \\
& & $\$ 60,001-\$ 75,000$ & $40 \%$ & $47 \%$ \\
\hline
\end{tabular}

Note: The Medicare levy is currently an additional 1.5 per cent of taxable income, above a threshold that varies by family type. In modelling the impact of the package, we assumed that families held a sufficient level of private health insurance to avoid paying any further Medicare surcharge.

\section{Social welfare reforms}

There were two major considerations underlying the social welfare reforms announced in the Government's original tax package. The first was that any 
substantial shift in the tax mix away from income taxes and towards indirect taxes always creates a need for comprehensive compensation packages (Harding, 1998; Liberal and National Country Parties, 1991). This is because there are a substantial number of families that do not pay sufficient income tax to be compensated for their extra indirect taxes via income tax cuts (such as age pensioners and unemployed families).

The second was that the various programs of government assistance were heading in the direction of being out of control due to the proliferation of programs, all with exceptionally complicated means tests and eligibility rules (Harding, 1997a). Some of the new programs introduced by the Howard Government had exacerbated this trend, because of their preference for delivering assistance on the tax side rather than the outlay side. Thus, as at the end of 1999 the 'family tax assistance Part A' delivered income tax reductions to almost exactly the same families as received 'family allowance' from the Department of Family and Community Services. Very sensibly, therefore, the government also used the tax reform package as an opportunity for a 'spring clean' of the various programs providing assistance to families with children.

The social welfare side of the government's original tax reform package thus comprised four major components:

(1) restructured and increased payments to families;

(2) increases in pensions and benefits;

(3) rationalised child care benefits; and

(4) savings bonuses for aged persons and self-funded retiree

\section{Payments to families}

The family assistance reforms proposed by the government in the original tax package were not amended as part of the subsequent deal with the Australian Democrats. The government is rolling ten current forms of family assistance into two new family assistance programs - Family Tax Benefit Part $A$ for all families with children and Family Tax Benefit Part B for single income families with children (including sole parents).

Looking at Family Tax Benefit Part A first, the amalgamation of the existing Family Allowance and Family Tax Assistance does not result in significant structural change in the payments, as very much the same types of families receive these payments. Three features of the proposed changes are, however, especially significant. The first is the reduction in the current 50 per cent taper applying to the assistance given to lower income families to 30 per cent. This change will thus reduce effective marginal tax rates by 20 per cent for those families currently affected by the income test for the maximum rate of family allowance.

The second key feature is that at the upper end of the income distribution, at incomes ranging from about $\$ 66,000$ to $\$ 80,000$, the 'sudden-death' income test currently applying to both Minimum Family Allowance and Family Tax Assistance is to be replaced by a 30 per cent taper. A third key feature is that the 
tension between the currently asset-tested Family Allowance and the non-assettested Family Tax Assistance is to result in a liberalisation of the means-test, with the proposed new Family Tax Benefit being income-tested but not asset-tested. Figure 1 illustrates the effect of the proposed new system, with the white areas showing the increases in assistance and gentler slopes on the 'proposed system' lines reflecting the lower tapers applicable under the proposed new system.

\section{Figure 1: Comparison of Current and Proposed Systems in July 2000, Family Tax Benefit Part $\mathbf{A}^{\mathrm{a}}$}

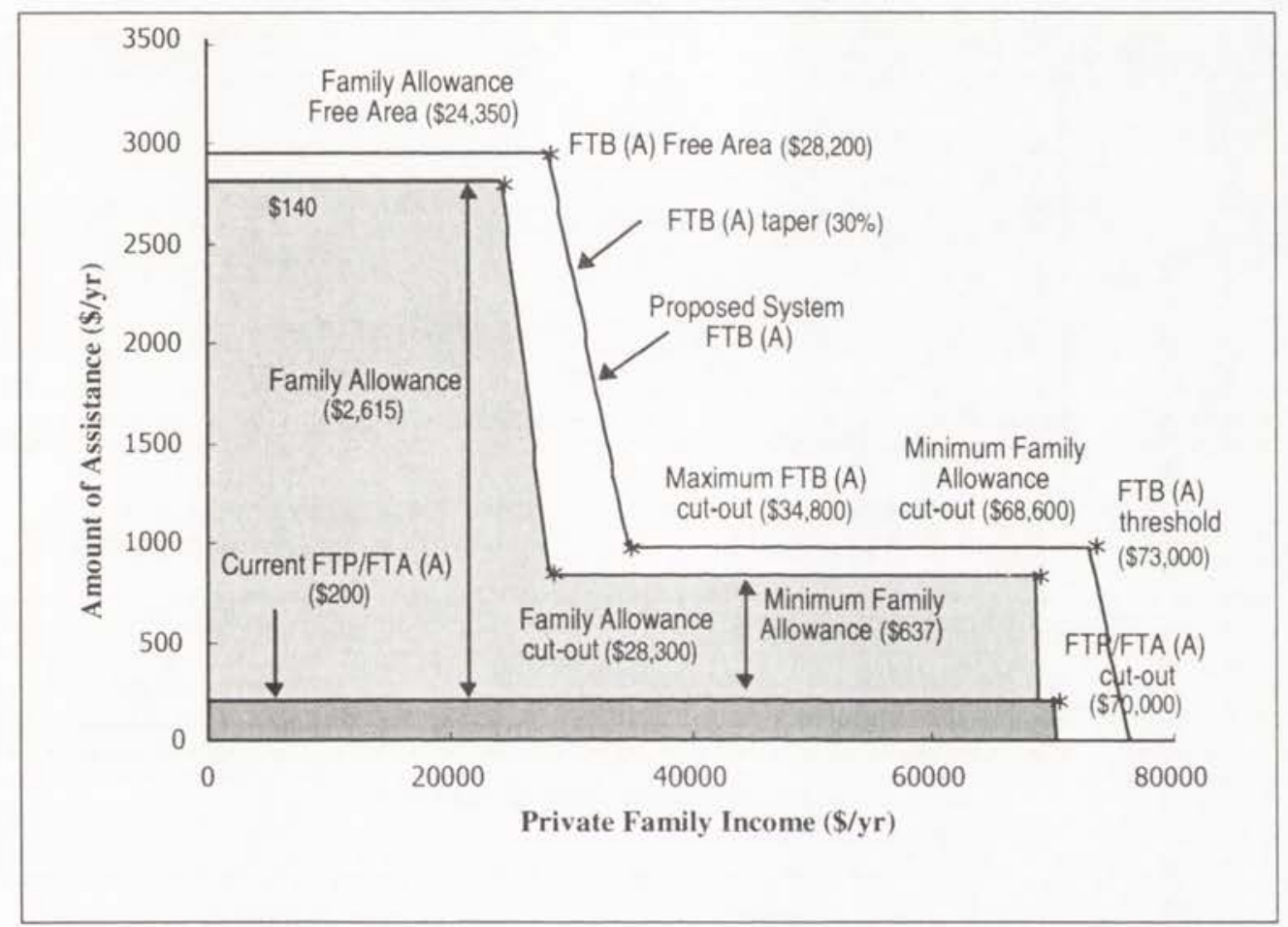

Source: Treasurer, (1998:62).

Note: $\mathrm{a}=$ For families with one child aged 13 years.

The reforms proposed under the second plank of the new Family Tax Benefit are more extensive. They involve amalgamation of the six programs currently delivering assistance to single income couples with children and sole parents into a single Family Tax Benefit Part B, with a withdrawal rate of 30 cents in the dollar on the spouse's income. This represents a sharp break with existing policy in a number of ways. First, the payment is not income-tested on the income of the primary income earner - which means that it will go to even the richest single income families and is effectively a universal payment for sole parents. Second, the existing sudden-death income test on Part B of the Family Tax Assistance has 
been abolished, as this payment has been incorporated into the new Family Tax Benefit Part B. Figure 2 illustrates the impact of the proposed changes in assistance under the Family Tax Benefit Part B for single income couples with one young child.

The Government is also rolling the two programs of child care assistance into a new Child Care Benefit, but this was not included in our modelling because of insufficient data about who benefits from the child care subsidies.

\section{Figure 2: Comparison of Current and Proposed Systems in July 2000, Family Tax Benefit Part $B^{\mathrm{a}}$}

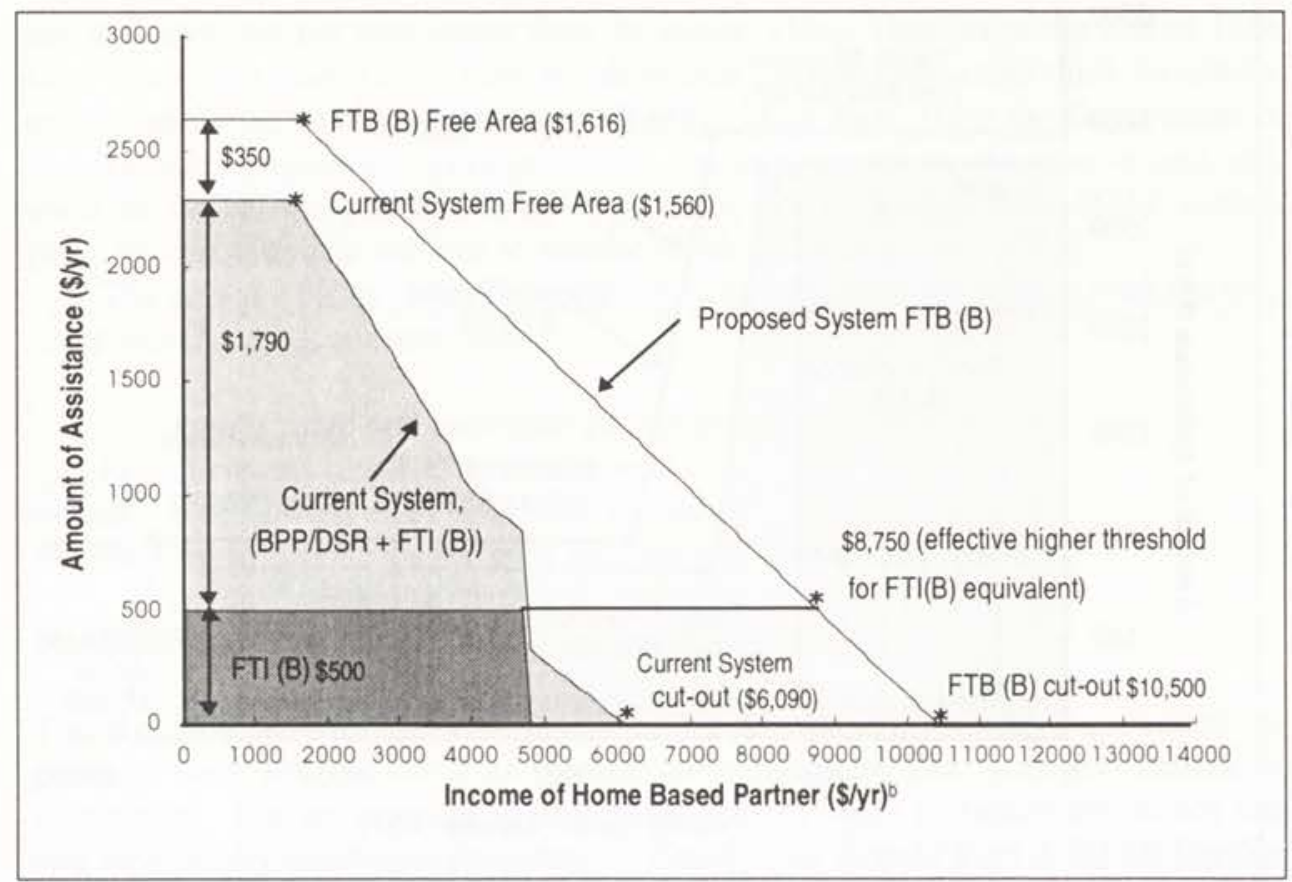

Source: Treasurer (1998:65).

Notes: $a=$ Single income couples with one child less than 5 years.

$\mathrm{b}=$ The income shown on the horizontal axis is the income of the secondary income earner, not of the family or the primary income earner. The proposed payment will no longer be tested on family income or primary earner income.

\section{Pensions and allowances}

In the original tax reform package the Government proposed increasing pensions and allowances - for the aged, the unemployed, the sick and so on - by 1.5 per cent more than the inflation rate. The adequacy of the compensation package for social security recipients subsequently emerged as one of the most controversial aspects of the tax reform debate. Ultimately the final agreement was to increase pensions and allowances by two per cent more than the inflation rate. (The 
income test for pensioners - thus including sole parents but not the unemployed - was also liberalised, with the taper rate being reduced from 50 to 30 cents in the dollar.)

The compensation mechanism for pensioners proposed under the original package was also subsequently shown to be flawed. This was because an existing Government commitment to set pensions at 25 per cent of male total average weekly earnings meant that the 1.5 per cent real compensation increase for pensioners would be rendered meaningless in about five years, as wages increased faster than prices (see Warren et al $1999 \mathrm{~b}$ for a fuller explanation). As a result, in the final tax reform package the compensation for pensioners was 'locked in', with the indirect tax compensation payment remaining a separately indexed component of the pension in future years.

\section{Other vulnerable groups}

Apart from social security recipients, there are other groups in the community that are generally considered to be at risk of inadequate compensation in the face of major shifts in the tax mix towards indirect taxes (Harding, 1998). These include early and self-funded retirees and those whose annual taxable incomes are too low for full or any compensation via income tax cuts (for example, those working parttime or part-year). The Government's original tax reform package was extended in two ways by the Senate to improve compensation for such groups.

First, the Government originally proposed an Aged Persons Savings Bonus for those aged 60 or more and an additional Self-Funded Retirees Supplementary Bonus for those of age pension age or over and not in receipt of social security the former payment being designed to compensate for the possible loss of the value of some assets after the tax mix shift and the latter to pick up those aged persons who would not be compensated via age pension increases. Concerns subsequently emerged about self-funded retirees who were below age pension age and not receiving any social security payments. As a result, in the final package the Government extended the Self-Funded Retirees Bonus to those aged 55 and over.

Another issue that emerged during the hearings by the Senate Committee was concern about those on low taxable incomes who were not receiving social security payments - and who would thus not be compensated via either income tax cuts or social security increases for their new indirect tax burdens. In the final package the Government agreed to establish a GST Assistance Scheme for Low Income Persons outside the social security net but, at the time of writing this article, no details of the Scheme have emerged.

\section{Simulating the Impact of Tax Reform}

How can we tell who will win and who will lose from complex tax reform packages? In all three of the major tax mix shift reforms proposed in the last two decades, microdata and microsimulation models have been used to estimate the 
distributional effects of the reforms (Treasury, 1985; Liberal and National Parties, 1991; Warren et al, 1999a and 1999b; Johnson et al, 1998). However, in the latest round of tax reform the Treasury departed from its own earlier practice by not using its PRISMOD microsimulation model as the basis of distributional impact estimates published in the Government's tax reform package (1.999).

This change in methodology stemmed from Treasury's concern about the accuracy of the 1993-94 Household Expenditure Survey (HES) conducted by the Australian Bureau of Statistics (Carnahan, 1998). There are two key problems with using the HES as the basis for microsimulation modelling of substantial tax reform packages. First, there is an imbalance between expenditure and income in the HES, with the average Australian household apparently spending more than its disposable income (Harding and Warren, 1998). In fact, the ABS (1995) specifically warns against using the difference between income and expenditure in the HES data as a measure of savings or dissavings. Second, the HES sample size is relatively small and, particularly for infrequently purchased consumer durables, one household behaving in an unusual manner in a small population sub-group may distort the average results for that population sub-group.

As a result of these types of concerns, instead of using estimates of gain and loss based on the representative sample of families captured in the HES, the Treasury constructed 'representative' or cameo household types. Two critical assumptions underlay the Government's estimates for cameo households of the net gains from the tax reform package. The first was that it was fair to assume that the prices facing each of the hypothetical households would rise by 1.9 per cent, which was the Treasury's estimated change in the CPI (excluding housing and tobacco price effects). It was thus assumed that the price increases facing different types of households would not vary greatly, despite differences in consumption patterns. This was a particularly important assumption as, in the original package, social security pensions were to be increased by the general CPI effect plus 1.5 per cent. If the general CPI effect did not provide an adequate indicator of the likely changes in prices for pensioners, then there was a possibility that social security recipients would not be adequately compensated for the shift in the tax mix towards consumption taxes.

The second critical assumption was effectively that dissaving did not occur or, if it did, it was not a problem that required addressing. This assumption was implicit in Treasury's calculation that the impact of the new indirect taxes would be limited to 1.9 per cent of current disposable income, rather than 1.9 per cent of current expenditure in cases where expenditure exceeded income.

These two key assumptions were of particular concern to the Senate Committee, which asked us to make alternative assumptions when simulating the distributional impact of the tax package. Consequently, we calculated groupspecific price effects for 29 sub-groups within the Australian population, using the HES data on consumption patterns and our STINMOD-STATAX microsimulation model (Lambert and Warren, 1999). For example, we estimated that the indirect tax changes in the final package would increase prices as measured by the CPI by 2.7 per cent, but that prices would increase by 3.05 per cent for age pensioners and 
only 2.16 per cent for single income couples with one child aged less than five years (Warren et al, 1999b). We also assumed that low income households with no private income of their own were spending 10 per cent more than their income and we included the impact of tobacco and house price increases in our estimates of the price changes likely to flow from the tax package.

Finally, another important issue was the timing of the simulation, because many of the indirect tax reforms were being phased in over a number of years and strong transitional effects were expected in the 12 months following the introduction of the new GST in July 2000. Our modelling showed the estimated impact of the tax reform package at July 2000. This meant that average weekly earnings, social security payment rates and so on were forecast forwards to that point in time. However, in calculating the impact of the indirect tax changes it was assumed that the GST had been in operation for two years, so that the estimated impact on prices in 2001-02 was used to calculate the expected increase in the indirect taxes paid by households. This is because there were expected to be major transitional effects in the first year of operation of the GST and our modelling attempted to show the likely medium term impact once these transitional effects had worked their way through the system. Similarly, the Government intends that social security recipients will remain two per cent better off once these effects have eventuated, and the modelling incorporates that intention.

\section{Impact of the Original Package}

Although the impact of the package differs greatly for different types of families, the results for a single taxpayer provide a useful illustration of the general differences between the original and the final tax reform packages. First, low income households dependent on social security did better out of the final package, because of the additional 0.5 per cent real increase in pensions and allowances. Second, the removal of food from the GST base reduced the impact of the indirect tax changes for all single taxpayers so that those who still received the full income tax cuts were better off under the final package than under the original package. Third, those with taxable incomes above $\$ 50,000$ a year did less well under the final package, because of the reductions in their income tax cuts. All of these effects are clearly illustrated in Figure 3, where single taxpayers earning $\$ 50,000$ or less are better off under the final package, while those earning more than $\$ 50,000$ are better off under the original package.

Another notable feature is that the gains from the package are relatively slight for those in the $\$ 20,000$ to $\$ 30,000$ private income range. This is because the income tax cuts for those in this zone are relatively small and largely offset by their new indirect tax burdens. 


\section{Figure 3: Percentage Gain in Disposable Income Under Original and Final Tax Reform Packages for Single Taxpayer}

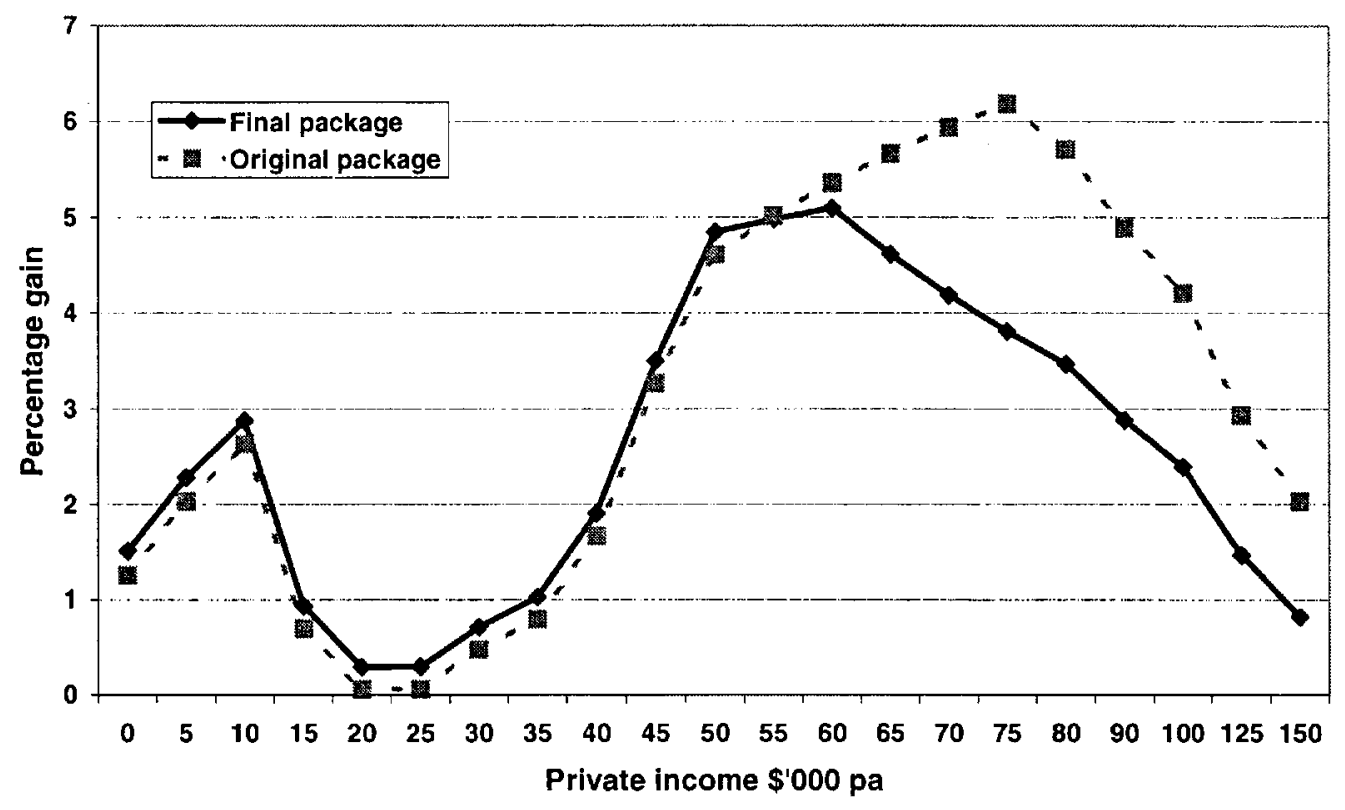

Note: It is assumed in this and in all subsequent cases that those with very low levels of private income are receiving social security payments.

\section{Distributional Impact of Final Package}

How will different types of families benefit from the tax reform package? Generally, those without children fare less well than those with children - and single income families fare better than dual income families. Figure 4 looks at the impact of the tax reform package on the disposable incomes of those without children. In essence, the gain curve is shifted to the right for dual income families, as at least one person needs to be earning more than $\$ 50,000$ before the major impact of the income tax cuts is felt. It is notable, however, that the percentage increase in disposable income never exceeds 5.5 per cent for these families without children.

In contrast, as Figure 5 illustrates, the gains for some single income families with children exceed 10 per cent. Single income families with children are the big winners out of the tax package. This is because families with only one earner receive all of the Family Tax Benefit Part B, regardless of the primary earner's income, and also receive substantial personal income tax cuts as their income increases up to around $\$ 50,000$. These gains come on top of those received through the Government's Family Tax Initiative, introduced in 1997. (However, there is some evidence that single income families fared relatively poorly during the 1982 to mid 1990s period (Harding, Szulkaska and King, 1999). 
Figure 4: Estimated Percentage Gain in Disposable Income Under Final Tax Reform Package for Those Without Children

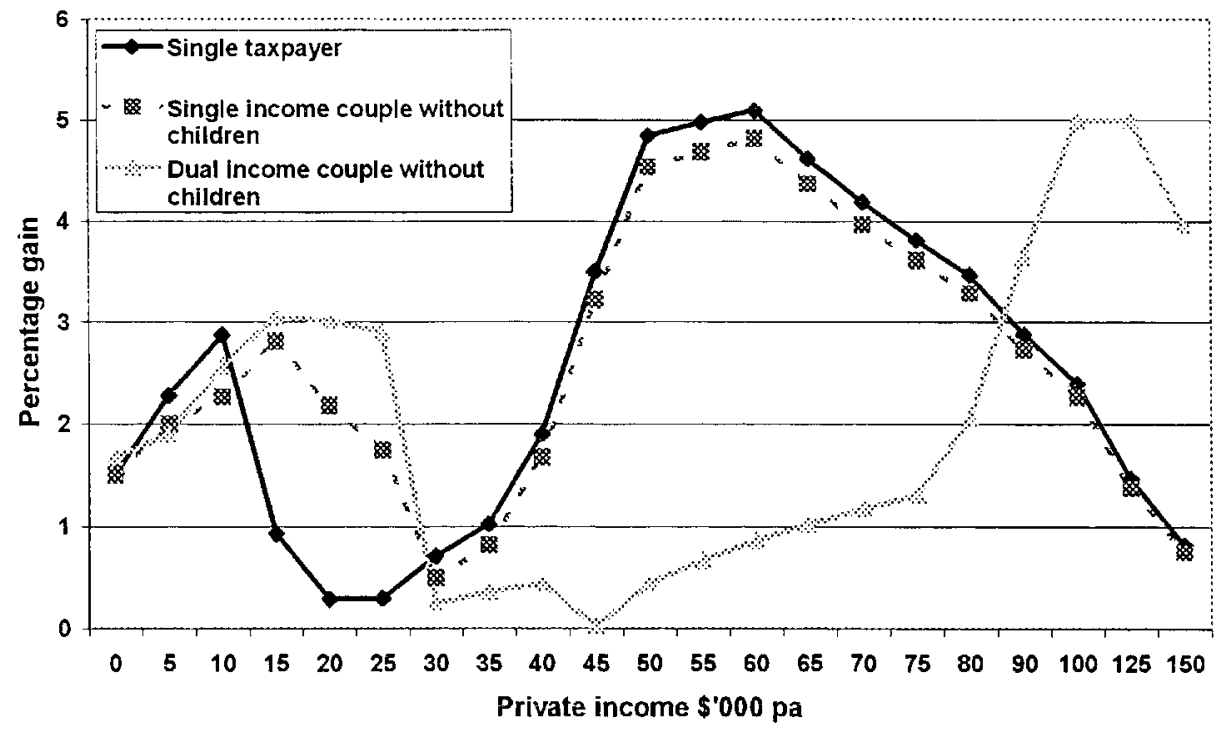

Figure 5: Estimated Percentage Gain in Disposable Income Under Final Tax Reform Package for Single Income Families

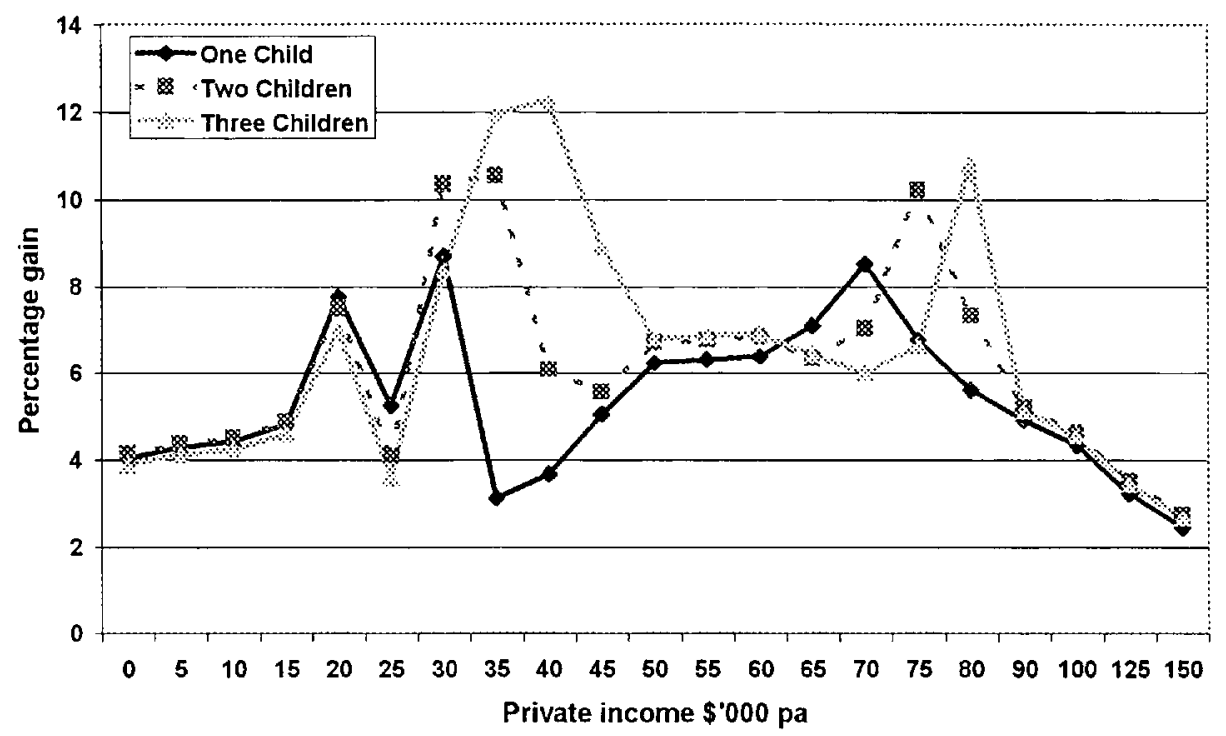

Note: In all graphs, one child means a child aged less than five years; two children means one aged less than five years and one aged 5-12; and three children means one aged less than five years and two aged 5-12. The figures underlying all of these graphs were published in the Weekend Australian on June 19 and can be freely downloaded from the NATSEM website www.natsem.canberra.edu.au. 
Those single income families whose primary earner receives between $\$ 30,000$ and $\$ 40,000$ benefit most because they receive the effect of both an increase in the threshold for their main family tax payment (Family Tax Benefit Part A) and a reduction in the withdrawal rate for those benefits. The more children they have, the greater the child-related benefits and the higher the gains.

The boost to disposable income for families with income around $\$ 70,000$ comes from the changes to the income test for Family Tax Benefit Part A, which is no longer 'sudden-death', but now has both a higher threshold and a 30 per cent taper. This means a boost to payments for those single earner families with children with an income above $\$ 70,000$. The gains for single income and families above $\$ 70,000$ are quite significant and more accentuated than for dual income families with children (as noted below).

The situation for dual income couples differs from that of single income couples for two primary reasons. Firstly, the income tax cuts are less significant for dual income families on comparable family incomes up to $\$ 70,000$, since the greatest tax cuts accrue to those with individual incomes between $\$ 38,000$ and $\$ 50,000$.

Furthermore, the Family Tax Benefit Part B is not means-tested on the primary earner's income, only on the secondary earner's income. This contrasts with the situation for comparable payments under the current system, where a means test is applied to the primary earner's income. Obviously, dual income couples have this Family Tax Benefit Part B payment means-tested away, resulting in less of a boost to the disposable income of families with incomes of over $\$ 70,000$.

However, dual income families still benefit just like single income families, from the increase in the Family Tax Benefit Part $A$ threshold and the introduction of a 30 per cent taper.

\section{Sole parents}

Sole parents generally receive above average benefits from the tax reforms. Those fully dependent upon the pension benefit from the substantial increases in the new Family Tax Benefits Parts $\mathrm{A}$ and $\mathrm{B}$ and the increase in the base pension rate. Those with low private incomes benefit from the liberalisation in the pension income test, although these gains are slightly offset by the removal of the Sole Parent Rebate from the tax system. At modest private income levels, around $\$ 30,000$ to $\$ 40,000$, sole parents benefit from the reduction in the income test taper for family assistance from 50 cents to 30 cents in the dollar. And at higher private income levels sole parents benefit from both the income tax cuts and the removal of the primary earner income test from Family Tax Benefit Part B. The latter change results in the 'spike' for net gains for sole parents with incomes around $\$ 70,000-\$ 75,000$ shown in Figure 6. 
Figure 6: Estimated Percentage Gain in Disposable Income for Dual Income Families and Sole Parents

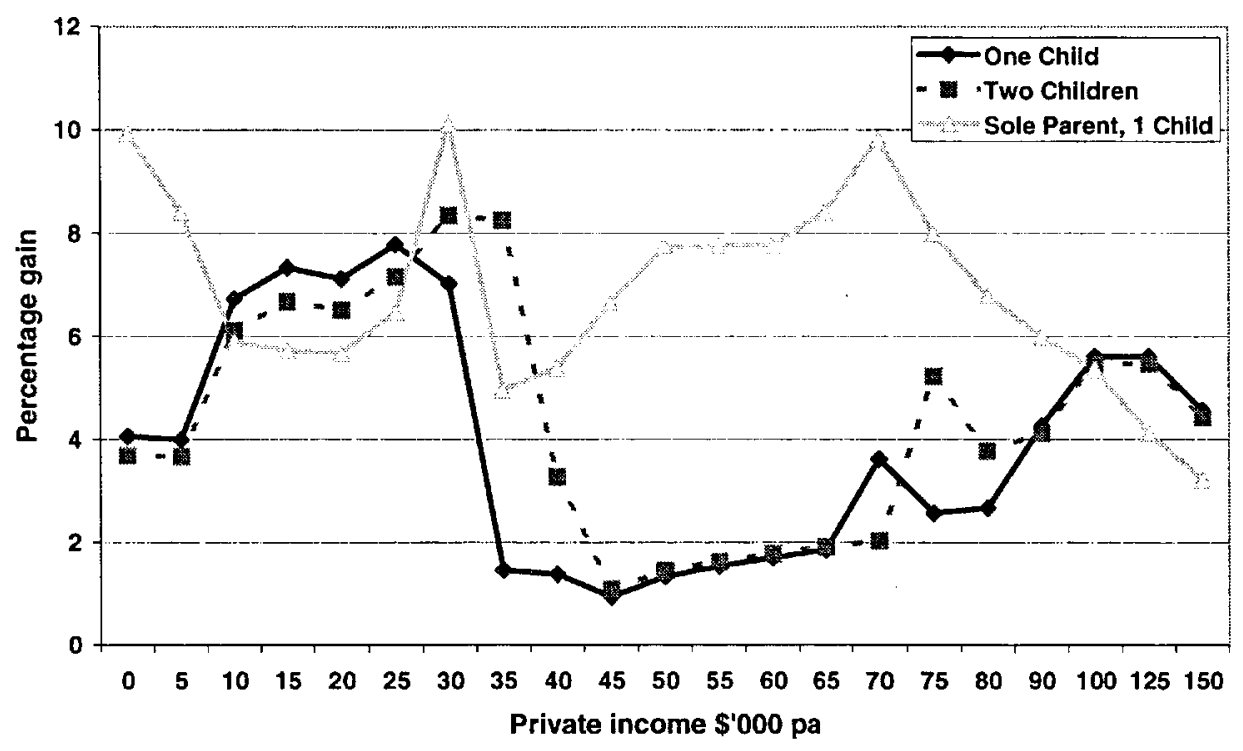

Figure 7: Estimated Percentage Gain in Disposable Income for Age Pensioners

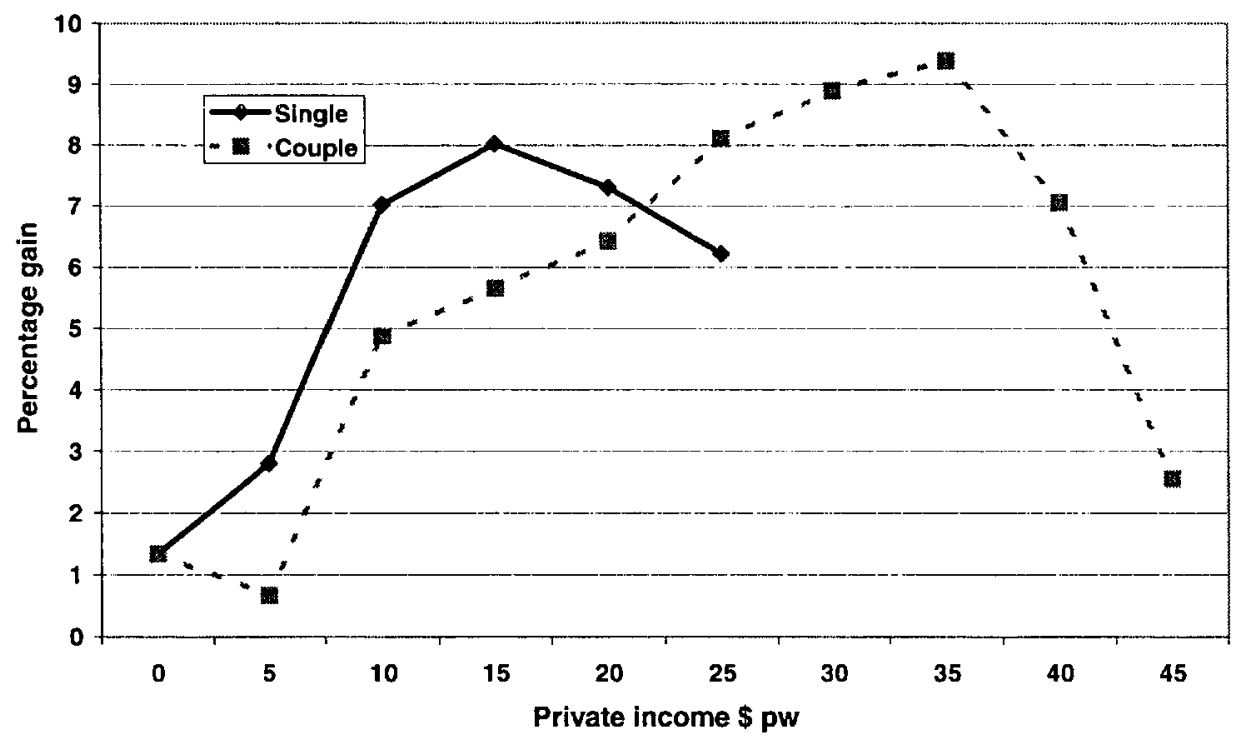




\section{Age pensioners}

Age pensioners were one of the groups that featured prominently in the negotiations about the shape of the final tax reform package. Their different consumption patterns meant that they faced substantially higher than average increases in prices under the original proposals, and they benefited greatly from the removal of food from the revised GST base. For example, while we estimated that the final tax package would increase prices by 0.5 per cent less than the original tax package, for age pensioners the removal of food resulted in more than double the average benefit (Warren et al, 1999b). Age pensioners also benefited from the increase in real pensions, up two per cent in the final package compared with only 1.5 per cent in the original package. Nonetheless, Figure 7 makes clear age pensioners with substantial private income fared much better from the tax package than those fully dependent on their pension.

\section{Conclusions}

In July 2000 Australia will have a new tax system. The tax reform package involves cuts in income tax, the introduction of a new 10 per cent GST on a wide base but excluding basic foods, and the abolition of some other indirect taxes. The income tax cuts may still appear to some to be large and unfair. But it must be recognised that they essentially only represent the return to taxpayers of the tax bracket creep that inflation has imposed upon them since 1993 (Carmody, 1999). Other research suggests that the income tax system became more progressive between the early 1980s and the mid 1990s and that there were evident political limits to how much longer the trend towards higher marginal tax rates for average earners could continue (Harding, 1997b, 1998).

The indirect tax reforms ultimately accepted by the Senate were clearly less efficient than those originally proposed by the Government, but they did help to improve the equity of the overall package. The exclusion of food from the GST base was particularly important to the aged and those on low incomes.

All estimates of the distributional impact of tax reform packages are of necessity only a rough guide to likely outcomes. Our estimates incorporate important assumptions about behaviour, including how quickly businesses will pass on tax cuts or increases and ignoring any possible changes by consumers in their purchasing patterns after the tax change. However, our analysis of the 2000 Australian tax reform package suggests the following general conclusions:

- $\quad$ the biggest winners are single income couples with children;

- families with children generally do better than those without;

- $\quad$ sole parents fare relatively well;

- age pensioners with substantial non-pension income make larger gains than those fully dependent on social security; 
- the gains from the package are very modest or almost non-existent for some groups, including those without children with incomes around $\$ 30,000$ to $\$ 35,000$; and

- those individuals with incomes between $\$ 38,000$ (around average weekly earnings) and $\$ 50,000$ do particularly well as a result of the income tax changes.

\section{References}

Australian Bureau of Statistics (1995), 1993-94 Household Expenditure Survey Australia: Summary of Results, Catalogue No 6530.0, AGPS, Canberra.

Carmody, G. (1999), 'Fairer but more complex and less efficient', Weekend Australian, June 19, GST Liftout, p. 6.

Carnahan, M. (1998), 'Does Demand Create Poor Quality Supply: A Critique Of Alternative Distributional Analyses', Taxation Policy Group, Commonwealth Treasury, August, mimeo.

Harding, A. (1997a), 'Tighter Targeting Revisited: Growing Problems Within the TaxTransfer System', Issues in Public Sector Change Seminar Series, University of Melbourne, 15 September.

Harding, A. (1997b), 'The Suffering Middle: Trends in Income Inequality in Australia 1982 to 1993/94', Australian Economic Review 30(4):341-58, December.

Harding, A. (1998), 'Equity Issues' pp. 71-94 in Abelson P. (ed.), The Tax Reform Debate - The Economics of the Options, Allen and Unwin, Sydney.

Harding, A. and N. Warren (1998), An Introduction to Microsimulation Models of Tax Reform, Report prepared for the Senate Select Committee for a New Tax System, 15 December.

Harding, A., A. Szukalska and A. King (1999), 'Changes in the Economic Fortunes of Australia's Children', NATSEM Income Distribution Report, No. 10, May.

Johnson, D., S. Cowling and G. Harding (1998), 'Compensation and Tax Reform', paper presented at the EMBA Seminar on Tax Reform, Sydney, 10 December.

Lambert, S. and N. Warren (1999), 'STINMOD-STATAX: A Comprehensive Model of the Incidence of Taxes and Transfers in Australia', National Centre for Social and Economic Modelling, University of Canberra, (Technical Paper No. 16).

Liberal and National Parties (1991), Fightback!, Pirie Printers, Canberra, 21 November.

Treasurer (1998), Tax Reform: Not a New Tax, A New Tax System, AGPS, Canberra.

Treasury (1985), Reform of the Australian Tax System: Draft White Paper, AGPS, Canberra, June. 
Warren, N., A. Harding, M. Robinson, S. Lambert and G. Beer (1999a), Distributional Impact of Possible Tax Reform Packages, Report prepared for the Senate Select Committee for a New Tax System, 1 April.

Warren, N., A. Harding, S. Lambert and M. Robinson (1999b), 'Distributional Impact on Households of the Australian Y2K Tax and Transfer Reforms', Paper presented at the Conference on Reform of Tax and Tax Transfers in Germany and Australia - and the Ralph Report, UNSW Cliffbrook Campus, Sydney, 1-3 September. 